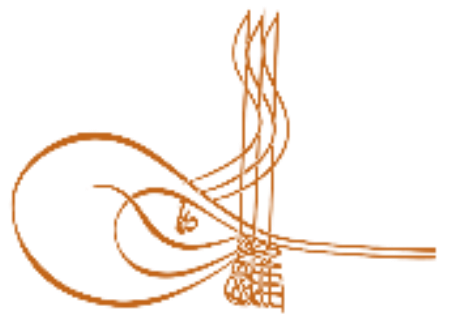

www.turkishstudies.net/turkishstudies
Turkish Studies

eISSN: $1308-2140$

Research Article / Araştırma Makalesi

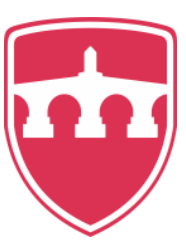

INTERNATIONAL

BALKAN

UNIVERSITY

Sponsored by IBU

\title{
Pandemilere Antropolojik Bakış: Koronavirüs (Covid-19) Örneği
}

Anthropological Overview of Pandemics: Coronavirus (Covid-19) Example

\author{
Vahdet Özkoçak ${ }^{*}$ - Fırat Koç ${ }^{* *}$ - Timur Gültekin ${ }^{* * *}$
}

\begin{abstract}
Anthropology is involved through scientists belonging to its sub-branches related to the ongoing debates in all scientific fields dealing with the subject and fulfills its duty in laying the foundations of the future while contributing to possible explanations with the establishment of the bridge between the past and the present. Perhaps the most important benefit of interdisciplinary studies is that it gives a wide range of perspectives to events and facts; With this aspect, we frequently encounter interdisciplinary studies. There are several approaches to the COVID -19 pandemic, which has become the common problem of the world today as a global disaster. From an anthropology perspective, it appears as a multidimensional pattern expressed by the concept of pandemic. In this study, pandemics in the past, underlying diseases, human migrations, factors affecting the rate of spread of outbreaks, cultural factors that caused the disease to become a global pandemic and the results of pandemics were discussed. With the studies on pandemics experienced in the past and the main approaches of anthropology, a conclusion was made on the possible balance sheet of the epidemic by establishing a cause-effect relationship. It is thought that pandemics, which are renewed by mutations, seen in a wide variety of geographical regions, spread across the continents and spread all over the world, and caused by viruses without population immunity, will be repeated as long as the world returns. In this case, it is necessary to ensure that the socio-economic, cultural, financial and educational costs are minimized by taking the previous experiences into consideration in order to meet and overcome pandemics.
\end{abstract}

Structured Abstract: Anthropology is in close contact with almost every branch of science, from sociology to biology, from paleontology to geography, from odontology to osteology, from medicine to philosophy, from geology to archeology, from psychology to economic sciences. Anthropology is one of the sub-branches of Anthropology and medical anthropology is a science in which public health is evaluated from a social and

\footnotetext{
* Dr. Öğr. Üyesi, Hitit Üniversitesi, Fen-Edebiyat Fakültesi, Antropoloji Bölümü Asst. Prof. Dr., Hitit University, Faculty of Science And Letters, Department of Anthropology ORCID 0000-0002-4603-2548

vahdetozkocak@gmail.com

*** Ar. Gör., Hitit Üniversitesi, Fen-Edebiyat Fakültesi, Antropoloji Bölümü

Res. Asst., Hitit University, Faculty of Science And Letters, Department of Anthropology

ORCID 0000-0002-8558-6308

kocfiratkoc@gmail.com

**** Prof. Dr., Ankara Üniversitesi, Dil ve Tarih Coğrafya Fakültesi, Antropoloji Bölümü

Prof. Dr. Ankara University, Faculty of Languages History and Geography, Department of Anthropology

ORCID 0000-0003-3520-5308

tgultekin@ankara.edu.tr

Cite as/ Atıf: Özkoçak, V., Koç, F., Gültekin T. (2020). Pandemilere antropolojik bakış: koronavirüs (covid-19) örneği,

Turkish Studies, 15(2), 1183-1195. https://dx.doi.org/10.29228/TurkishStudies.42679

Received/Geliș: 15 March/Mart 2020

Accepted/Kabul: 25 April/Nisan 2020

Copyright $(\mathrm{C}$ MDE, Turkey

Published/Yayın: 30 April/Nisan 2020

CC BY-NC 4.0
} 
cultural perspective in national and international contexts, especially biological anthropology and social anthropology. Anthropologists working in this field carry out epidemiological studies on the disease experiences of the society, their perception of diseases and treatment methods. Infectious diseases are as old as human history. People have lived a collective life, from 6.5 million to 2.6 million years. In this gathering life, they were mainly fed with plants and insects and carcasses left over from other animals. Approximately 2.6 million years ago, we see that people started hunting together with gathering due to the development in tool technologies. In human history, we can say that deaths in infectious diseases are more than deaths in wars. The deaths of millions of people from the past to the present may be the cost of these radical changes in human life. Infectious diseases caused collective deaths even in developed and high-wealth countries such as the United States until the 21 st century. Today, a new pathogen is included in the health literature almost every week and new infectious diseases are identified every two to three years. From the perspective of anthropology to infectious diseases, the emergence and spread of such diseases among human populations are associated with some environmental factors. Society's experiences against infectious disease are very important. The emergence of diseases, migrations and spreading caused by migrations, methods of treating diseases, factors affecting treatment, the transformation of diseases into epidemics and rapidly spreading into pandemics and the consequences of this situation are of interest in Anthropology. In this context, the aim of the study is to reveal what epidemics are today and what societies mean in terms of the outbreaks faced by people and the strategies they have developed against these epidemics. Many important pandemics have been recorded in human history, including smallpox, plague, dengue virus, AIDS, influenza, severe acute respiratory syndrome (SARS), West Nile disease and tuberculosis. Flu outbreaks are unpredictable but recurring events that can have serious consequences on communities around the world. Flu outbreaks have occurred about three times per century since the 1500s. For example, in the 20th century, there were three influenza outbreaks called "Spanish flu" in 1918-1919, "Asian flu" in 1957-1958 and "Hong Kong flu" in 1968-1969. The Spanish flu in 19181919, which killed more than 50 million people as the most devastating epidemic in the world history, was recorded. General features of pandemics; It can be listed as the rapid spreading in wide geographical areas, spreading independently of the seasons, emergence due to viruses that are renewed as a result of mutations, causing fatal results, poor population immunity or even absence, leading to changes and transformations in people's lifestyles. Infectious diseases have infected millions of people in the past, causing large-scale serious illnesses and mass deaths in a large population. These outbreaks were not only limited to casualties, but left deep traces in social life. We should consider infectious diseases as a social phenomenon that affects many areas including both economy and social life and politics. For example, the plague epidemic led to the death of more people than many wars. The first plague epidemic that has been recorded is known as the "Plague of Justinian". Pandemics have many dramatic consequences. Collective deaths, social chaos, cultural and economic collapses can be listed as some of these important problems. At this point, it will be useful to evaluate the events and facts from an anthropological perspective. Scientists related to the sub-branches of anthropology, such as Physical Anthropology, Medical Anthropology and Socio-Cultural Anthropology, can make various predictions based on previous experiences of the causes of diseases, the cultural factors that accelerate the spread, what kind of consequences pandemics can cause and what can happen in the post-epidemic process. Understanding past population dynamics is a major challenge for anthropological research, but it is the basis for studies in this area. Questions about the origin of ethnic groups, the causes of cultural change and the beginning of agricultural practices can be answered by examining past migrations and other demographic processes. Pandemic has serious negative effects. Infectious diseases can infect millions of people, causing widespread deaths in a large population. Pandemics pose a serious threat to the same global economy. Longterm economic instability may occur due to the economic burdens, treatment costs, production losses and indirect costs caused by the epidemic process. However, border security of countries is under threat and national security is a problem. Schools that are closed during these processes cause great damage that is difficult to compensate in terms of social and cultural life, tourism, agricultural and commercial activities and investments. Correct interventions that can be done effectively and quickly can increase the survival rate of people. Having an effective and efficient emergency management forms the basis of combating pandemic. At this point, protection of both human health and economic continuity can be defined as a matter of survival. It is obvious that the world has lessons from the COVID-19 pandemic against possible future outbreaks. In the light of the experience gained in the COVID-19 process, the creation of new protocols and emphasis on medical R\&D studies have become an important need, even an imperative. We think that a new world order will emerge after the "COVID-19 pandemic".

Keywords: Pandemic, anthropology, coronavirüs, COVID-19, epidemiology, disease. 
Öz: Antropoloji, insanı konu edinen tüm bilimsel alanlarda süregelen tartışmalarla ilgili alt dallarına mensup bilim insanları vasıtasıyla dâhil olmakta ve geçmiş ile günümüz arasındaki köprünün kurulmasıyla muhtemel açıklamalara katkı yaparken, geleceğin temellerinin atılmasında da üzerine düşen görevi yerine getirmektedir. Disiplinler arası çalışmaların belki de en önemli getirisi, olaylara ve olgulara çok çeşitli bakış açıları kazandırmasıdır; bu yönüyle disiplinler arası çalışmalara günümüzde sıklıkla rastlamaktayız. Bugünlerde küresel bir felaket olarak tüm dünyanın ortak sorunu haline gelen COVID -19 pandemisine yönelik çeşitli yaklaşımlar mevcuttur. Antropoloji perspektifinden bakıldığında pandemi kavramının ifade ettikleri çok boyutlu bir örüntü olarak karşımıza çıkmaktadır. Bu çalışmada geçmişteki pandemiler, hastalıkların altında yatan nedenler, insan göçleri, salgınların yayılım hızını etkileyen faktörler, hastalıkların küresel çapta bir pandemiye dönüşmesine sebep olan kültürel ögeler ve pandemilerin doğurduğu sonuçlar ele alınmıştır. Geçmişte yaşanılan pandemilere dair gerçekleştirilen çalışmalar ile antropolojinin temel yaklaşımları arasında neden-sonuç ilişkisinin kurularak salgının muhtemel bilançosu üzerine çıkarımlar yapılmıştır. Mutasyonlarla yenilenen, çok çeşitli coğrafi bölgelerde görülen, kıtaları hızla aşıp tüm dünyaya yayılan ve popülasyon bağışıklığının olmadığı virüslerin yol açtığı pandemilerin dünya döndüğü sürece yineleneceği düşünülmektedir. $\mathrm{Bu}$ durumda yapılması gereken pandemilerin karşılanması ve üstesinden gelinmesi noktasında sosyo-ekonomik, kültürel, finansal, eğitsel maliyetlerin önceki tecrübeler göz önünde bulundurularak alınacak önlemler ile en aza indirilmesini sağlamaktır.

Anahtar Kelimeler: Pandemi, antropoloji, koronavirüs, COVID-19, epidemiyoloji, hastalık.

\section{Giriş}

Kelime anlamı insan bilim olan Antropoloji insanı sosyo-kültürel, biyolojik ve morfolojik özellikleri bakımından ele alan bilim dalıdır (Akın, Özkoçak ve Gültekin, 2017).

Antropoloji, sosyolojiden biyolojiye, paleontolojiden coğrafyaya, odontolojiden osteolojiye, tıptan felsefeye, jeolojiden arkeolojiye, psikolojiden iktisadi bilimlere hemen her bilim dalıyla yakın temastadır. Antropoloji bilimi başta biyolojik antropoloji ve sosyal antropoloji olmak üzere çeşitli alt dallara ayrılır (Özkoçak, 2018).

Antropolojinin alt dallarından tıbbi antropoloji ise toplum sağlığının ulusal ve uluslararası bağlamlarda sosyal ve kültürel perspektiften değerlendirildiği bilim dalıdır. Bu alanda çalışan Antropologlar toplumun hastalık deneyimleri, hastalıkları algılayış biçimleri ve tedavi yöntemleri üzerine epidemiyolojik çalışmalar gerçekleştirirler (Jaiswal, 2018).

Bunun yanında Afet Antropolojisi, çalı̧̧ma alanları bakımından afet zararlarının azaltılması ve yönetilmesi ile afet risk yönetim süreçlerini başarılı kılmak açısından çok önemlidir (Varol ve Gültekin 2016).

Enfeksiyon hastalıkları insanlık tarihi kadar eskidir. İnsanların günümüzden yaklaşık 6.5 milyon yıldan 2.6 milyon yıla kadar toplayıcı bir yaşam sürmüştür. Bu toplayıcı yaşamda daha çok bitki ve böcekler ve diğer hayvanlardan arda kalan leşlerle beslenmekteydiler. Günümüzden yaklaşık 2.6 milyon yıl önce ise alet teknolojilerindeki gelişmeye de bağlı olarak insanların toplayıcılıkla birlikte avcılık yapmaya başladığını görmekteyiz. Avcı toplayıcı yaşam yaklaşık olarak günümüzden 10 bin yıl önceye kadar devam etmektedir. Tarım devrimi ve ardından insanların tarıma geçişi ile yerleşik hayata geçtiğini görmekteyiz. Bu aşamadan sonra insan hayatında, alışkanlıklarından kültürüne ve beslenmesine kadar köklü değişimler yaşanmıştır. Bu değişim ve dönüşümlerin hepsi insanlık tarihi açısından bir dönüm noktası niteliğindedir. Yerleşik hayata geçilmesiyle birlikte, tarımda elde edilen ürünler ve bunların ticarileşmesi, pazarların kurulması gibi gelişmeler birçok sağlık problemini de beraberinde getirmiştir. Hastalıklar böylelikle pazar yerlerinde kolayca insanlar arasında salgınlara dönüşmüştür. Hayvanların evcilleştirilmesi ve hayvanlarla temasın artması gibi birçok neden ile hayvanlardan insanlara hastalıkların geçişi kolaylaşmıştır. 
İnsanlık tarihinde enfeksiyon hastalıklardaki ölümlerin, savaşlardaki ölümlerden daha çok olduğunu söyleyebiliriz. Geçmişten günümüze milyonlarca insanın ölümü belki de insan yaşamındaki bu köklü değiş̧imlerin bir bedeli olabilir (Esen, 2017).

Enfeksiyon hastalıkları 21. yüzyıla kadar Amerika Birleşik Devletleri gibi gelişmiş ve refah seviyesi yüksek ülkelerde dahi toplu ölümlere yol açmıştır. Günümüzde neredeyse her hafta sağlık literatürüne yeni bir patojen dâhil edilmekte ve her iki-üç yılda bir yeni enfeksiyon hastalıklar tanımlanmaktadır. Enfeksiyon hastalıklara Antropoloji perspektifinden bakıldığında, bu tür hastalıkların insan popülasyonları arasında ortaya çıkışı ve yayılımı, bazı çevresel faktörlerle ilişkilendirilmektedir. Bunlar nüfus artışı, çarpık kentleşme, endüstriyel sağlıksız gıdaların sık tüketimi, radyasyon etki alanlarının artması, küreselleşme, hava kirliliği, yanlış kullanımlar nedeniyle antibiyotiklere patojenik direncin gelişmesi gibi etkenlerdir. Bununla birlikte kültürel ilişkiler de hastalığın ortaya çıkmasının ardından yayılım hızını etkileyebilmektedir. Tüm bu antropojenik küresel değişikliklerin önümüzdeki yıllarda daha da hızlanması beklenmektedir. $\mathrm{Bu}$ noktada yenilenen, mutasyona uğramış patojenlerin tehdidi özellikle de gelişmekte olan ülkeler bağlamında dikkate değerdir. Önceki enfeksiyon sürecinin yıpratıcılığ 1 , yetersiz beslenme, sağlık hizmetlerine ulaşım ve altyapı problemleri göz önünde bulundurulduğunda refah seviyesinin enfeksiyon hastalıklarla mücadeledeki önemi daha iyi anlaşılacaktır (Singer, 2009).

Bulaşıcı hastalığa karşı toplumların geliştirdiği deneyimler çok önemlidir. Hastalıkların ortaya çıkışı, göçler ve göçlerin sebep olduğu yayılımlar, hastalıkların tedavi ediliş yöntemleri, tedaviye etki eden faktörler, hastalıkların salgın haline gelip hızla yayılarak pandemiye dönüşmesi ve bu durumun yarattığı sonuçlar Antropolojinin ilgi alanına girmektedir (Kırık ve Özkoçak, 2020).

$\mathrm{Bu}$ çerçevede çalışmanın amacı, geçmişten günümüze insanların karşılaştıkları salgınlar ve bu salgınlara karşı geliştirdikleri stratejiler ile günümüzde yaşadığımız salgın olayı ve toplumlar açısından bu salgınların ne anlama geldiği ortaya konmaya çalışılacaktır.

\section{1. İnsanlık Tarihindeki Büyük Pandemiler}

Pandemi sözcüğü eski Yunan dilinde "tüm insanlar" anlamını karşılamaktadır. Uluslararası sınırları ve hatta kıtaları aşan, dünya genelinde yayılan enfeksiyon hastalıklar "pandemi" olarak tanımlanmaktadır. Dünya Sağlık Örgütü (DSÖ) pandemi kavramını insan popülasyonunun immünolojik dirence sahip olmadı̆̆ olarak açiklamaktadır (Qiu, Rutherford, Mao ve Chu, 2017).

İnsanlık tarihinde, çiçek hastalığı, veba, dang virüsü, AIDS, grip, şiddetli akut solunum sendromu (SARS), Batı Nil hastalığı ve tüberküloz dâhil olmak üzere birçok önemli pandemi kaydedilmiştir. Grip salgınları dünya çapında toplumlar üzerinde ciddi sonuçları olabilecek öngörülemeyen ancak tekrarlayan olaylardır. Grip salgınları 1500' lerden beri her yüzyılda yaklaşık üçer kez ortaya çıkmıştır. Örneğin 20. yüzyılda, 1918-1919'da “İspanyol gribi”, 1957-1958'de “Asya gribi" ve 1968-1969' da ise "Hong Kong gribi" olarak adlandırılan 3 grip salgını yaşanmıştır. Dünya tarihindeki en yıkıcı salgın olarak 50 milyondan fazla insanı öldüren 1918-1919 yıllarında yaşanan İspanyol gribi kayda geçmiştir (Qiu, ve diğ. 2017).

\section{Pandemilerin genel özellikleri;}

- Geniş coğrafi alanlarda hızlı yayılımların görülmesi,

- Mevsimlerden bağımsız olarak yayılması,

- Mutasyonlar sonucu yenilenen virüsler nedeniyle ortaya çıkması,

- $\quad$ Ölümcül sonuçlar doğurması,

- $\quad$ Nüfus bağışıklığının çok zayıf olması hatta hiç olmaması,

Turkish Studies, 15(2) 

siralanabilmektedir.

İnsanların yaşam tarzlarında değişim ve dönüşümlere yol açmaları olarak

Enfeksiyon hastalıkları geçmişte milyonlarca insanı enfekte ederek büyük bir popülasyonda geniş çaplı ciddi hastalıklara ve toplu ölümlere neden olmuştur. Bu salgınlar sadece can kayıpları ile sınırlı kalmayıp, toplumsal hayatta derin izler bırakmıştır. Enfeksiyon hastalıkları hem ekonomi ve sosyal hayatı hem de siyaseti içine alan birçok alana etki eden toplumsal bir olgu olarak ele almamız gerekir. Örneğin veba salgını birçok savaştan daha fazla insanın ölmesine yol açmıştır. Kayıt altına alınan ilk veba salgını "Jüstinyen Vebası (Plague of Justinian)" olarak bilinmektedir. Hastalığın nerede ortaya çıktığına dair literatürde farklı bilgiler bulunmaktadır. Bunların başında Jüstinyen Vebası' nın Etiyopya' da ortaya çıkarak Mısır' a yayıldığı, daha sonra Filistin' e ulaşarak buradan Anadolu' ya geldiği ve daha sonra Konstantinopol (güncel ismiyle İstanbul)' e ulaştı̆̆ına yönelik yaklaşım gelmektedir (Retief ve Cilliers, 2005) (Şekil 1).

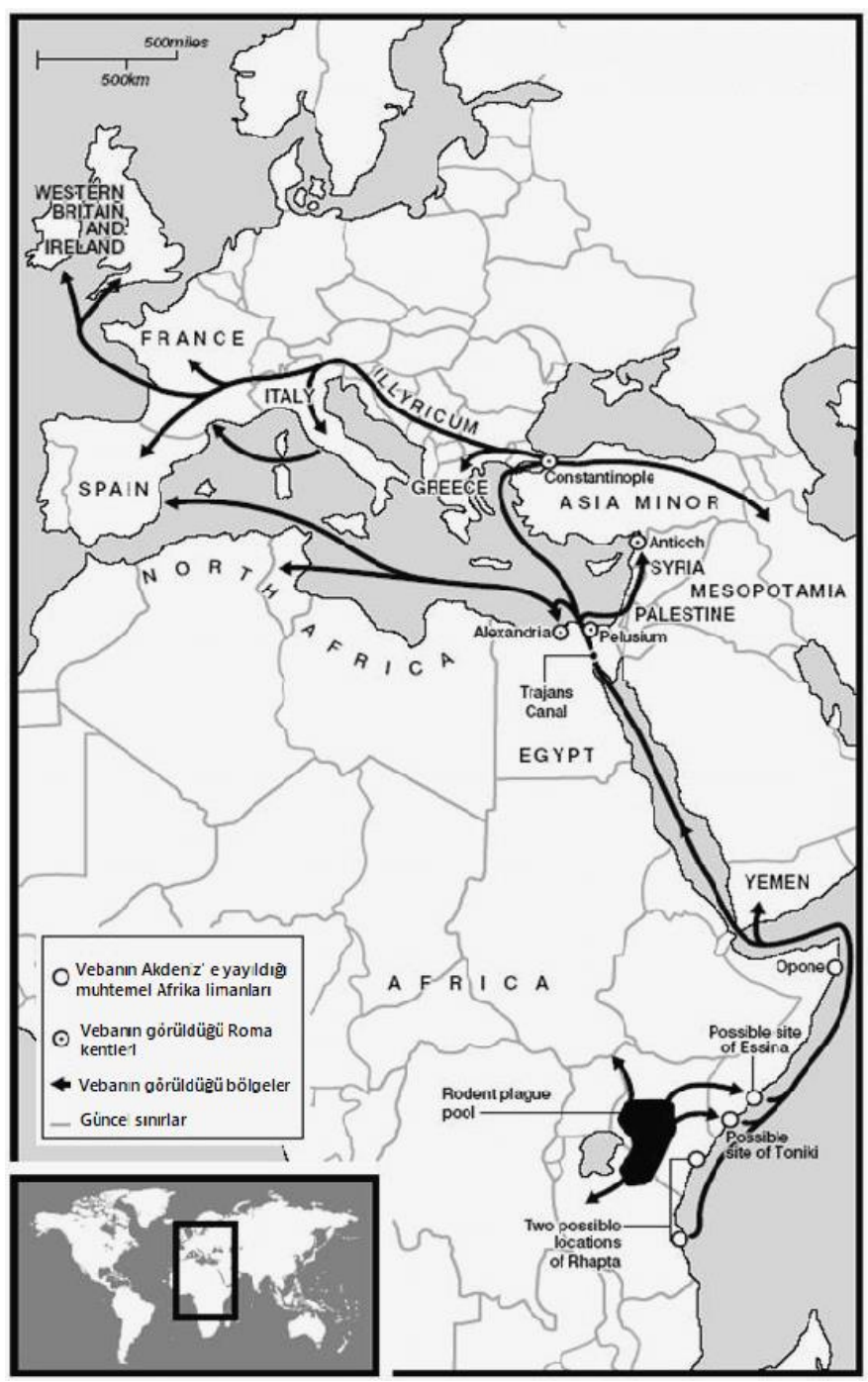

Şekil 1: Jüstinyen Vebasının ortaya çıktığı ve yayıldığı bölgeler (Laudisoit A. 2009). 
Damgaard ve diğ. (2018)' nin gerçekleştirdiği çalışmada yeni bulgular 1şı̆̆ında hastalığın izlerine ve yayılımına dair bambaşka bir güzergâhtan söz edilmektedir. Avrasya bozkırlarında bulunan 137 bireyin iskeletlerinden gerçekleştirilen DNA analizlerine göre Hunlar' da vebanın izlerine rastlanmıştır. Bununla birlikte gerçekleştirilen analizler Kara Veba gibi Jüstinyen Vebası' nın da pirelerden bulaşmasına imkân sağlayan mutasyonlara uğradığını ortaya koymuştur. Ancak, bunun 6.yüzyıldaki veba yayılımı ile ilişkisinin bilinmezliğini koruduğu da belirtilmiştir.

Başlarda hastalığın etkisinin az görüldüğ̈̈ bölgelerde tekrarlamasıyla salgın geniş bir coğrafyaya yayılmış ve tüm dünyayı yavaş yavaş enfekte etmiştir. Jüstinyen Vebası nedeniyle 25 milyona yakın insanın öldüğü ve tekrarladığı yıllarda 50 milyona yakın insanın hayatına mâl olduğu düşünülmektedir.

14. yüzyılda görülen "Kara Ölüm” olarak da bilinen veba salgınında Avrupa nüfusunun yarıs1 yok olmuştur. 1968-1969' da görülen Hong Kong gribi ise 1 milyon insanın ölümüne neden olmuştur (Wildoner, 2016).

15. ve 16. yüzyıllarda dünya genelinde görülmeye başlanan çiçek hastalığ 1 , insandan insana sıvı ve damlacık yoluyla bulaşan, ateşli seyreden ve döküntülü bir hastalıktır. 19. yüzyılın başlarında Anadolu'ya gelen çiçek hastalığı için Osmanlı Devleti'nin aşı çalışmaları yaptığı bilinmektedir. 18. yüzyılın sonunda Jenner tarafından bulunan aşı, 19. yüzyılda üretilerek kullanılmaya başlanmıştır (Halsall, 1998).

18. yüzyılın sonlarına doğru ortaya çıkan kolera salgını, 19.yüzyılın başlarında Anadolu'da da görülmüştür. Genel olarak ticaret yollarında bulunan illerde ve kıyı şeridinde etkili olan bu salgın, 19. yüzyılın sonlarına kadar çok sayıda ölüme sebep olmuştur. Karantina uygulamalarının ve ihracat sınırlamalarının örnekleri bu dönemde de görülmektedir. Defalarca tekrarlayan kolera salgınlarında dünya genelinde 1,5-2 milyona yakın insan hayatını kaybetmiş̧tir (Hays, 2005).

19. yüzyılın sonlarına doğru, Osmanlı İmparatorluğu'ndan ayrılan bölgelerden Anadolu'ya göçlerin başlamasıyla birlikte enfeksiyon hastalıklarının sayısının hızla arttığı görülmüştür. Zorlu hayat şartları, beslenme ve temizlik gibi konularda özensizlikler ve imkânsızlıklar nedeniyle bulaşıcı ve enfeksiyon hastalıkların yayılmasına uygun ortam hazırlanmıştır. Bununla birlikte cepheden gelen askerler, dini ziyaretlerden dönen hacılar ve tüccarlar da yayılımın hızlanmasına neden olmuşlardır (Çalık ve Tepekaya, 2006).

20. yüzyılın başında (1928) Alexander Fleming tarafından penisilinin keşfedilmesinin ardından enfeksiyon hastalıklarının tedavisinde yepyeni bir çağ açılışstır. Basit diş apselerinden bile binlerce hatta on binlerce insanın hayatını kaybettiği düşünüldüğünde penisilinin keşfi modern tıp alanı için çok önemli bir adımı simgelemektedir (Lewis, 2013).

Bugünlerde bütün dünyanın tek gündemi olan Koronavirüs ailesinin en tehlikeli alt türlerinden SARS CoV salgını (2003) sırasında, sadece 6 ayda dünya çapında 8000 enfekte bireyin kayıtlara geçtiği ve bunların 700' den fazlasının hayatını kaybettiği bildirilmiştir. Bu sayının neredeyse \%10' a yakın bir mortalite oranına tekabül ettiği göz önünde bulundurulduğunda durumun ciddiyeti daha iyi anlaşılacaktır (Wong \& Leung, 2007; Qiu ve diğ. 2017).

İlk olarak 2012 yılında görülen ve 3000'e yakın vaka ile küresel bir halk sağlığı tehdidi haline gelen bir başka koronavirüs türü olan MERS-CoV 2012 ise dört kıtada 27 ülkeye yayılmış ve 858 insanın hayatını kaybetmesine sebep olmuştur (Ay, 2020).

Aralı 2019'da Orta Çin'in en büyük şehri olan Vuhan'da ortaya çıkan Yeni Koronavirüs (COVID-19), yüksek ateş, öksürük ve nefes darlığı gibi solunum yolu belirtileri görülen hastalar üzerinde gerçekleştirilen araştırmalar sonucunda Ocak 2020'de tanımlanarak tıp literatürüne geçmiş bir virüstür (T.C Sağlık Bakanlığı, 2020). 
COVID-19 hastalığı 11 Mart 2020 tarihi itibariyle Dünya Sağlık Örgütü tarafından "pandemi" ilan edilmiştir (Şekil 2).

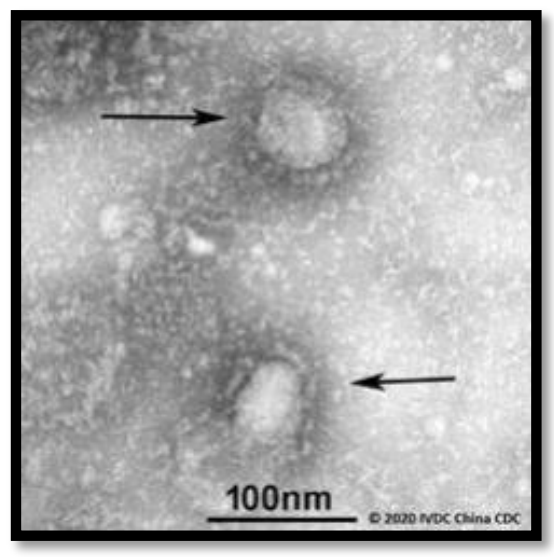

Şekil 2: COVID-19 elektron mikroskobu görüntüsü (T.C. Sağlık Bakanlığı, COVID-19 Rehberi)

Günümüze değin (Mart 2020) insanlarda 229E (HCoV-229E), OC43 (HCoV-OC43), SARSCoV, NL63, HKU1, MERS-CoV ve COVID-19 olmak üzere 7 tip Koronavirüs tanımlanmıştır (T.C Sağlık Bakanlığı, 2020).

Koronavirüsler hızlı mutasyona uğrayabilen virüsler olduğundan, yeni bir virüs ile enfeksiyonun ortaya çıkma ihtimali her daim bulunmaktadır. Hayvanlardan insanlara bulaş gerçekleșebilmektedir; insanlarda hastalığa neden olan Koronavirüsler'in yarasa, deve ve sığırlardan geçtiği düşünülmektedir (Oval1, 2020).

İnfluenza tüm ülkeleri etkileyen, en ciddi enfeksiyon hastalıklardan biridir ve küresel sağlığı tehdit etmektedir. Grip salgınları ciddi oranda mortaliteye neden olabilmektedir. Her yıl dünya çapında tahmini 1 milyar vaka, 3-5 milyon ciddi vaka ve 290 000-650.000 griple ilgili solunum yetmezliğine bağlı ölüm gerçekleşmektedir (WHO, Global Influenza Strategy 2019-2030).

Pandemiler ciddi sağlık sorunlarına ve ölümlere sebebiyet vermenin yanında, telafisi zor sosyal ve ekonomik sonuçlar da doğurmaktadır. Örneğin H1N1 (domuz gribi) virüsü, yayıldığı ülkelerde ölümle sonuçlanan vakalara ek olarak tarımsal faaliyetlerin ciddi anlamda yavaşlamasına ve turizm, eğitim, sağlık, teknoloji, ekonomi, finans vb. sektörlerin önemli ölçüde yıpranmasına da sebep olmuştur.

Salgınlar, sadece dünya nüfusu için değil, aynı zamanda ekonomisi için de ciddi bir tehdittir. Ekonomik kaybın etkisi ekonominin istikrarsızlığına neden olabilir. Etki, doğrudan maliyetler, uzun vadeli yük ve dolaylı maliyetlerdir. Örneğin, Ebola salgını Batı Afrika'daki ekonomiyi ciddi şekilde baltalamıştır. 2015 yılında Sierra Leone' deki Ebola salgınının doğrudan maliyeti, hastane giderleri, personel ve ilaç temini olmak üzere toplam 6 milyar dolar olarak kayıtlara geçmiştir (Gostin ve Friedman, 2015).

Pandemiler sosyal hayatı da olumsuz yönde etkilemektedir. İnsanlar sosyal canlılardır; beslenme ve barınma gibi temel ihtiyaçların dışında eğitim, eğlence, aktivite, sanatsal faaliyetler ve turistik geziler gibi diğer gereksinimlerinin karşılanması ve sosyalleşmesi gerekir. Bu dönemlerde seyahat kısitlamaları, okulların kapanması, tiyatro, konser vb. sanatsal faaliyetlerin ve spor müsabakalarının ertelenmesi, akademik toplantıların iptal edilmesi gibi önlemler nedeniyle gündelik hayat olağanüstü bir hal almakta ve sosyal aktivitelerin işleyişi aksamaktadır. Enfeksiyon hastalıklar, 
tıpkı savaşlar ve finansal krizler gibi insanların yaşamlarına ve geçim kaynaklarına zarar vermektedir. Bu nedenle salgınların önlenmesi sadece sağlık meselesi olarak değil, ulusal ve küresel güvenliğin temel ilkesi olarak görülmektedir.

\section{Pandemilerin Antropolojik Açıdan Önemi}

Yukarıda değinildiği gibi pandemiler pek çok dramatik sonuçlar doğurmaktadır. Toplu ölümler, sosyal kaoslar, kültürel ve ekonomik çöküşler bu önemli sorunlardan bazıları olarak sıralanabilir. İşte bu noktada Antropolojik perspektiften olayları ve olguları değerlendirmek faydalı olacaktır. Antropolojinin, Fiziki Antropoloji, Tibbi Antropoloji ve Sosyo-Kültürel Antropoloji gibi alt dallarıyla ilgili bilim insanları, hastalıkların ortaya çıkma nedenleri, yayılımı hızlandıran kültürel faktörler, pandemilerin ne tür sonuçlara sebep olabileceği ve salgın sonrası süreçte nelerin yaşanabileceğine dair önceki tecrübelerden yola çıkarak çeşitli öngörülerde bulunabilirler. Örneğin yirminci yüzyılın başında İskoç askerler ile çiftçilerin boy uzunluklarının karşılaştırıldığı bir çalışmada kullanılan veriler üzerinden 2013 senesinde bazı analizler gerçekleştirilmiştir. O dönem "Rus Gribi (H1N1)" olarak da bilinen pandemi esnasında dünyaya gelen bireylerde gelişimsel açıdan anlamlı bir geriliğin bulunduğu ortaya konmuştur (Riggs ve Cuff, 2013).

Fiziki Antropolojinin temel veri toplama teknikleri olarak kabul edilen Antropometrik ölçümler bu örnekteki gibi Oksoloji alanıyla yani en genel tanımıyla Gelişimbilim ile dirsek temasındadır ve Seküler Trend (büyüme eğilimi) çalışmalarının geliştirilmesi bakımından büyük önem taşımaktadır (Özkoçak, Akın ve Gültekin, 2017).

Antropoloji alanında enfeksiyon hastalıkların kontrolüne ve yayılımların önlenmesine yönelik bazı çalışmalara da rastlanmaktadır. Antropologlar, salgınlara dair kronolojik incelemelere ve epidemiyolojik çalışmalara katkı sağlarlar. Bu sayede salgın süreci hazırlıkları hızlandırılarak sınır güvenliklerinin güçlendirilmesi, nüfusun sosyo-ekonomik düzeyinin korunması, sağlık hizmetlerinin aksatılmaması sağlanmakta ve gıda kıtlığına yönelik önlemler alınabilmektedir (Lynteris 2018).

Enfeksiyon hastalıklar "1rkçılık" olarak nitelendirebileceğimiz bir takım istenmeyen eğilimleri de tetikleyebilmektedir. İnsanın neden-sonuç ilişkisini kurma çabasının içerisinde her zaman "kim" sorusu da yer almaktadır. Bu soru insanın başına gelmiş ve geçmekte olan olayların, olguların sorumlusunu arayan bir sorudur. Yanıtın doğru veya yanlış olmasından daha önemlisi inandırıcı hatta inanılmak istenen olmasıdır. Bu yaklaşım, dolaylı olarak etnosantrik ve ırkçı sonuçlar doğurabilir. Günümüzdeki bu enfeksiyon hastalıkların, ileriki ay ve yıllarda sınırların daha keskin bir şekilde çizilmesine ve bu bağlamda ulusalcılık, ulusların üstünlüğü gibi argümanların devreye girmesine yol açabileceği düşünülmektedir.

Pandemiler sırasında en büyük zararı düşük sosyo-ekonomik statüye sahip insanların görmesi beklenebilir. Bunun yaşanılan koşullarla yani barınma, beslenme ve sağlık hizmetlerine ulaşım imkânlarıyla ilişkili olduğu söylenebilir. Bununla birlikte düşük eğitim düzeyine sahip toplumlarda, enfeksiyon hastalıkların yayılımına yönelik alınması gereken tedbirlerin tam anlamıyla uygulanmadığına dair çeşitli çalışmalar da mevcuttur. Aslında milletlere özgü hastalıklar yoktur, çoğu genellikle coğrafyalarla ilgilidir. Hastalıkların mortalite ve morbidite oranları popülasyonların yaşam koşullarına ve biyolojik farklılıklarına göre değişim gösterebilir. Ancak bu farklılıkları yalnızca belirli toplumlara atfetmek ırkçı bir tutum olarak karşılanmaktadır (Økland, 2019).

2003 yılında Kanada Toronto'da 44 kişinin ölümüne yol açan SARS hastalığı Kanadalılar tarafından "Çin Hastalığı" olarak nitelendirilmiş ve Toronto'daki Çin mahallesindeki restoranlar haftalarca boş kalmıştır. Hastalığın Kanada'ya gelmesinin esas nedeni Hong Kong, Guangzhou, Singapur ile Toronto arasındaki yoğun iş bağlantıları nedeniyle gerçekleştirilen sık seyahatler olarak bildirilmiştir (Keil ve Ali, 2006). 
Çin'de Yeni Koronavirüs COVID-19' un ortaya çıkmasından birkaç hafta sonra, virüsün kökeni hakkında yanıltıcı söylentiler ve komplo teorileri ortaya atılmış, 1 rkçı söylemler baş göstermiştir. 21. yüzyılın en önemli olgularından biri sosyal medyada, virüsün ülkelere yayıldığı hıza eşdeğer bir biçimde spekülatif ve kimi zaman yanlış bilgiler de tüm dünyaya yayılmıştır. Böylelikle ciddi bir panik ortamı yaratılmış ve insanlar yanlış yönlendirilmiştir. İhtiyaç fazlası alışverişler, bazı günlük tüketim ürünlerinin ve maske, eldiven, koruyucu gözlük gibi tıbbi malzemelerin fiyatlarında yüksek oranlarda artışa sebep olmuştur. Bununla birlikte virüsün Çin'den ortaya çıkmasından hareketle, Çinli turistler, öğrenciler tepkiyle karşılaşmış ve Asya ile yürütülen ticari faaliyetler, Çin restoranları da bu ırkçı akımdan olumsuz yönde etkilenmiştir. Öyle ki Çin'e hiç ayak basmamış ama Çinli gibi görünen insanlar bile bu süreçte çeşitli tepkilerle karşılaşmışlardır (Karafillakis Martin ve Preet, 2020).

Yukarıda pandemilere yönelik örnekler verilerek bu karanlık süreçlerin Antropolojik açıdan ne tür anlamlar ifade ettiklerine dair çeşitli çıkarımlar yapılmışıtır. Antropologlar, enfeksiyon hastalıkların pandemiye dönüşme sürecindeki sosyo-kültürel ve biyolojik sebeplere odaklanırlar; geçmişte yaşanan pandemilerin Antropolojik sonuçlarına bakarak gelecekte yaşanabilecek pandemiler sonrasında gerçekleşmesi muhtemel sonuçlara dair derinlemesine çıarımlar yaparlar.

\section{Tartışma ve Sonuç}

Geçmiş nüfus dinamiklerini anlamak Antropolojik araştırmalar için büyük bir zorluk olsa da bu alandaki çalışmalara temel teşkil etmektedir. Etnik grupların kökeni, kültürel değişimin nedenleri ve tarım uygulamalarının başlangıcına dair sorular, geçmişteki göçler ve diğer demografik süreçler incelenerek cevaplanabilir.

Battaglia ve diğ. (2013) tarafından yürütülen bir çalışmada Orta ve Güney Amerika'da toplanan yaklaşı 400 Yerli Amerikan Y kromozomunun çoğunun neredeyse Amerikan yerlilerinde gözlemlenen Y filogenisinin tek kolu olan haplogrup Q'ya ait olduğu ve ayrıca Meksika'nın ilk göç (Kolombiya üzerinden güneye doğru) dalgası için bunun bir işaret olduğu bildirilmiştir. And Dağları'nda ise, Meksika Platosu'nda görülenden farklı bir Y kromozom varyasyonu saptanmıştır ve bunun tarımın başlamasıyla tetiklenen demografik bir değişim olduğu belirtilmiştir (Battaglia ve diğ. 2013).

İnsan genomunun sadece küçük bir bölümünü temsil etmesine rağmen, mtDNA insanın evrimsel tarihini aydınlatma noktasında oldukça güçlü olmuştur. Genotipleme teknolojisi geliştikçe ve karşılaştırmalı veri tabanları büyüdükçe, mtDNA çalışmaları için Antropolojik ve Genetik verilerin öneminin artacağı söylenebilir. Özellikle, antik kalıntılardan DNA kurtarmanın mümkün olmasıyla, araştırmacıların insan evrimine dair derinlemesine ve aydınlatıcı bilgiler edinebilmesinin olasılı̆̆ da artacaktır. Antik (eski) DNA çalışmaları daha önce karşılaşılmayan primatlara, türlere ve popülasyonlara dair keşifler yapabilmemize olanak tanımaktadır. Geliştirilen analitik teknikler ve oluşturulan veri tabanları 1şığında, genetik verilerin hala en anlaşılır ve en geçerli bilgileri sunduğunu görmekteyiz. Arkeolojik kanıtlar, jeolojik veriler ve tarihsel kayıtların genetik verilerle birlikte kullanılarak gerçekleştirilen çalışmaların güvenilirliğinin arttığı da söylenebilir (Çetli, Tatar ve Özkoçak 2019).

Antik DNA çalışmaları, moleküler teknikler vasıtasıyla iskelet kalıntılarından, cinsiyet tespiti, göç yollarının belirlenmesi, geçmişteki hastalıklara dair çıkarımlar yapılabilmesi, filogenetik araştırmaların gerçekleştirilmesi, hayvan ve bitkilerin tarihsel gelişiminin incelenmesi, beslenme şeklinin belirlenmesi ve kültürel çıkarımlar yapılabilmesine olanak tanırlar (Tekeli ve Elma, 2016).

Maliyet ve zaman açısından sağladığı avantajların yanında Antik DNA tekniği sayesinde hastalıkların cinsiyetlere göre dağılımları, yayılım alanları ve hastalığa dair mutasyonlarla ilgili bilgilere de erişilebilmektedir. Örneğin Ortaçağ İngiltere'sinde vebaya neden olan bakteri 400 y1llık bir diş kalıntısından tespit edilmiştir (Kefi, 2011). 
DNA örnekleri diş kökleri ve pulpa kısımlarında daha iyi korunsa da istisnai örneklere de rastlanmaktadır. 1991 yılında Alp Dağları'nda rastlanan “Buz Adam” olarak adlandırılan buluntu, bölgenin fiziki koşulları sayesinde oldukça iyi korunmuş adeta bir mumya formunda ele geçirilmiştir. Mide içeriğinden alınan örnekler 1şığında Buz Adam'ın helikobakter piloriden müzdarip olduğu bildirilmiştir. Bununla birlikte ileri derecede diş deformiteleri de tespit edilen Buz Adam'ın dişlerinde ileri derecede periodontit ve kırmızı kompleks bakterilerine de rastlanmıştır (Stone ve Ozga, 2019).

Geçmişe yönelik veriler irdelendiğinde günümüze ışık tutarak karanlıkta kalan sorularımızı aydınlatabilirler. 2011 senesinde Meksika'da gerçekleştirilen bir çalışmada influenza enfeksiyonu geçiren normal değerlere sahip ve obeziteli gebe kadınların hastane kayıtları incelenmiştir. Her iki grubun da hastalık esnasında solunum sıkıntısına girmedikleri rapor edilmiştir. Klinik bulgular açısından influenza enfeksiyonu ile benzerlikler taşıyan COVID-19 virüsü ile ilgili olarak obezitenin bir dezavantaj olmadığı sonucuna varılabilir (Zeron HM. 2011).

Barrett ve diğ. (2008) tarafindan gerçekleştirilen bir çalışmada pandemilerin benzerlikleri ve farklılıkları ile yol açabileceği sonuçlar hakkında derinlemesine incelemeler yapılarak pandemi süreçlerinde oluşan panik durumlarına da değinilmiştir. Bununla birlikte sosyal izolasyonun gerekliliği, hastalık zincirinin yalnızca titizlikle uygulanan önlemlerle kırılabileceğine yönelik çıkarımlar yapılmıştır. Bu çalışmada geçmişten günümüze uyarlanabilecek pek çok örnek ve düşünce yer almaktadır. Bunların başında tüm dünyada hükümetlerin alacağı önlemlere ve kararlara bireylerin büyük bir özveriyle katkı sağlaması ve riayet etmesi gerektiğidir.

Tüm olağanüstü durumlarda olduğu gibi bugünlerde yaşanmakta olan COVID-19 Pandemisi sürecinde de tüm insanlığı ve toplum sağlığını ilgilendiren konularda çeşitli karşıt görüşlere ve tartışmalara rastlanmaktadır. Bu süreçte, tüm görüşlere açık bir şekilde bilimsel veriler doğrultusunda önlemler alınarak sürecin doğru yürütülmesini sağlamak toplumlar açısından hayatidir.

Acar (2020)'ın çalışmasında ise başka bir belirsizlik olan pandemi sürecinin turizm sektörü üzerine olası etkileri konu edilmiştir. COVID-19 virüsünün etki alanı ve yayılım hızı ele alındığında, pandemi sürecinin uluslararası turizm faaliyetleri üzerindeki olası etkilerinin tahmin edilebilmesinin mevcut verilerle pek mümkün olmadığı yönündeki görüşünün aksine, yaşantımızın normale dönmesi için ihtiyaç duyacağımız zaman aralığının her geçen gün daha da arttığı açıktır.

COVID-19 sürecinin küresel ekonomi üzerindeki etkileri doğrultusunda yatırımcıların tercih edebilecekleri yatırım araçlarının ele alındığı bir çalışmada ise mevcut belirsizlikler nedeniyle kısa vadeli yatırımlardan ziyade uzun vadeli planların yapılması gerektiği belirtilmiş ve özellikle virüsün daha az yayılım gösterdiği ülkelerde yatırım yapılmasının faydalı olabileceği öngörüsü vurgulanmıştır. Ayrıca finans sektörünün pandemi sürecindeki belirsizlik ve olumsuzluklardan ciddi anlamda etkilendiği, sürecin uzaması halinde işlerin daha da kötüye gideceği belirtilmiştir (Zeren ve Hizarc1, 2020).

Güncel ve küresel bir sorun olarak pandemi kavramı, birden fazla bakış açısına ve yaklaşıma muhtaçtır. Antropoloji de bu yaklaşımların başında gelmektedir. Özellikle bu tür olağanüstü durumların karşılanması ve kovuşturulması aşamalarında ilgili alt dallarıyla Antropoloji çok önemli bir yere sahiptir.

İnsanlık tarihinde birçok önemli pandemi kaydedilmiştir. Pandemiler sonrası tüm dünyada yaşanan krizler sağlik, ekonomi ve hatta ulusal güvenlik gibi konularda çok büyük olumsuzluklara neden olmuştur.

"Pandemi" terimi uzun bir geçmişe sahip olmasına rağmen tanımı üzerinde halen mutabık kalınmış değildir. Genel olarak pandemi kavramını açıklamak için coğrafi açıdan geniş bölgelerde etkili olma, nüfusun söz konusu virüse karşı bağışıklığa sahip olmaması, kolay ve hızlı biçimde bulaşması gibi temel özelliklerden söz edilebilir. 
Pandeminin ciddi olumsuz etkileri vardır. Enfeksiyon hastalıklar milyonlarca insanı enfekte ederek büyük bir popülasyonda yaygın ölümlere sebep olabilir. Pandemiler aynı küresel ekonomi açısından da ciddi bir tehdit oluşturmaktadır. Salgın sürecinin getirdiği ekonomik yükler, tedavi masrafları, üretim kaybı ve dolaylı maliyetler nedeniyle uzun süreli ekonomik istikrarsızlıklar meydana gelebilmektedir. Bununla birlikte ülkelerin sınır güvenlikleri tehdit altında kalmakta ve ulusal güvenlik bir problem olarak karşımıza çıkmaktadır. Bu süreçlerde kapanan okullar, duran sosyal ve kültürel hayat, turizm, tarımsal ve ticari faaliyetler, yatırımlar açısından telafisi zor büyük hasarlara neden olurlar.

Etkili ve hızlı bir şekilde yapılabilecek doğru müdahaleler, insanların hayatta kalma oranlarının yükselmesini sağlayabilir. Etkili ve verimli bir acil durum yönetimine sahip olmak, pandemi ile mücadelenin temelini oluşturmaktadır. Bu noktada hem insan sağlığının, hem de ekonomik sürekliliğin korunması bir beka meselesi olarak tanımlanabilir.

Tüm dünyanın, bundan sonraki muhtemel salgınlara karşı COVID-19 pandemisinden çıkaracağı dersler olduğu aşikârdır. COVID-19 sürecinde edinilen tecrübeler 1şığında yeni protokollerin oluşturulması ve medikal ar-ge çalışmalarına ağırlık verilmesi önemli bir ihtiyaç, hatta zorunluluk halini almıştır.

Bu çerçevede artık yeni bir dünya düzeni oluşacaktır. Bu pandemi vasıtasıyla;

1- Globalleşmeyle birlikte sınırların kalktığına dair küresel görüşün aksine, bu tür bir salgınla birlikte, tüm ülkelerin sınırları içerisinde kalarak ulusal mücadele programlarını uygulamayı tercih ettiklerini,

2- Dünyaya hükmeden ve tüm dünya için "artık" bir tehdit haline gelen insanoğlunun aslında hastalıklara karşı ne kadar kırılgan olduğunu ve insanın doğanın bir parçası olarak doğayla uyum içerisinde yaşaması gerektiğini,

3- Gelişmiş, az gelişmiş ya da gelişmekte olan ülkelerde, zengin/yoksul fark etmeksizin her kesimde aynı çaresizliğin ve kaotik durumların yaşanabileceğini,

4- Özgürlük, varlıklı olmak ve daha fazlasını istemek gibi kavramların anlamlarının sorgulanması gerektiğini,

5- Bilimin bu tür afetlerde tek çözüm yolu olduğu ve özellikle de disiplinler arası çalışmalar vasıtasıyla yayılımın durdurulması, hastalıkların önlenmesi ve tedavi edilmesi aşamalarında başarılı olunabileceği,

6- Tıbbi malzeme, besin, temizlik diğer endüstri ürünlerinin üretiminin devamı ve sevkiyatlarının sağlanması gibi konularda bütüncül bir yaklaşım ile başarılı olunabileceği,

7- $\mathrm{Bu}$ tür küresel salgınların ciddiyet ve titizlikle yönetilmesi gereken süreçler olduğu açıkça görülmüştür.

\section{Kaynakça}

Acar Y. (2020). Yeni Koronavirüs (Covıd-19) Salgını Ve Turizm Faaliyetlerine Etkisi. Güncel Turizm Araştırmaları Dergisi. 4(1): 7-21. DOI: 10.32572/guntad.703410

Akın G. Özkoçak V. Gültekin T. (2017). Somatoskopi ve Antropometri Tekniklerinin Adli Bilimler İçin Önemi. Hitit Üniversitesi Sosyal Bilimler Enstitüsü Dergisi. 2017: 10(2). ss.703-714. doi: 10.17218/hititsosbil.328735.

Ay. A. (2020) Orta Doğu Solunum Sendromu Koronavirüsü Salgınları. ESTÜDAM Halk Sağll̆ğ Dergisi. 5(1): 158-167.

Battaglia, V., Grugni, V., Perego, U. A., Angerhofer, N., Gomez-Palmieri, J. E., Woodward, S. R., Semino, O. (2013). The first peopling of South America: New evidence from YChromosome Haplogroup Q. PLoS One, 8(8), e71390. doi:10.1371/journal. pone.0071390. 
Çalık R. Tepkaya M. (2006). Birinci Dünya Savaşı Esnasında Anadolu'daki Salgın Hastalıklar ve Ermeniler. Selçuk Üniversitesi Sosyal Bilimler Enstitüsü Dergisi. 16: 205-228.

Çetli E. Tatar D. Özkoçak V.(2019). Adli Bilimlerde DNA Parmak İzine Adli Genetik ve Adli Antropolojik Bakış. Bitlis Eren Üniversitesi Fen Bilimleri Dergisi. 1545-1556.

Damgaard, P. D. B., Marchi, N., Rasmussen, S., Peyrot, M., Renaud, G., Korneliussen, T., ... \& Baimukhanov, N. (2018). 137 ancient human genomes from across the Eurasian steppes. Nature. 557:369-374. doi.org/10.1038/s41586-018-0094-2

Esen A. (2017). Sıhhî-İ İctimâî Coğrafya Kitaplarına Göre İç Anadolu'da Görülen Salgın Hastalıklar (1922-1926). Ankara Üniversitesi Türk İnk1lâp Tarihi Enstitüsü Atatürk Yolu Dergisi. 60: 73-90.

Gostin, L. O., \& Friedman, E. A. (2015). A retrospective and prospective analysis of the west African Ebola virus disease epidemic: robust national health systems at the foundation and an empowered WHO at the apex. The Lancet, 385(9980), 1902-1909.

Halsall P. (1998). Modern History Sourcebook: Lady Mary Wortley Montagu (1689-1762): Smallpox Vaccination in Turkey. Yayımlanmamış Doktora Tezi, Fordham University.

Hays JN. Epidemics and Pandemics: Their Impacts on Human History. ABC.-Clio. 2005.

Jaiswal A. Meaning and Scope of Medical Anthropology. Patshala. Pondicherry, 2018.

Karafillakis E. Martin S. Preet R. (2020). The pandemic of social media panic travels faster than the COVID-19 outbreak. Journal of Travel Medicine. 1-5. DOI: 10.1093/jtm/taaa031/5775501

Kefi R. (2011). Ancient DNA investigations: A review on their significance in different research fields. International Journal of Modern Anthropology. 4:61-76. doi: 10.4314/ijma.v1i4.4

Keil R. Ali H. (2006). Multiculturalism, Racism and Infectious Disease in the Global City: The Experience of the 2003 SARS Outbreak in Toronto. TOPIA. 16: 23-48.

Kırık A. Özkoçak V. (2020). Yeni Dünya Düzeni Bağlamında Sosyal Medya ve Yeni Koronavirüs (COVID-19) Pandemisi, Sosyal Bilimler Dergisi / The Journal of Social Sciences, 45:133154. DOI: $10.29228 /$ SOBIDER.43146

Laudisoit A. (2009). Contribution to plague epidemiology in an endemic plague focus: the lushoto district (Tanzania). Yayımlanmamış Doktora Tezi, University of Antwerp: Antwerp.

Lewis K. (2013). Platforms for antibiotic discovery. Nature. 12: 371-382. doi: 10.1038/nrd3975

Lynteris C. Poleykett Branwyn. (2018). The Anthropology of Epidemic Control: Technologies and Materialities. Medical Anthropology. 37(6): 433-441.

Ovalı F. (2020). Yenidoğanlarda COVID-19 Enfeksiyonları. Anadolu Kliniği Tip Bilimleri Dergisi, 25(1): 23-35.

Økland H. Mamelund SE. (2019). Race and 1918 Influenza Pandemic in the United States: A Review of the Literature. Int. J. Environ. Res. Public Health. 16: 2487. doi:10.3390/ijerph16142487

Özkoçak, V. (2018). Antropometric Techniques used for Determining Aesthetic Anatomical and Anthropological Structure. Eurasian Academy of Sciences Eurasian Art \& Humanities Journal, 9, 30-38.

Özkoçak, V. (2018). Fiziki Antropoloji Yayınlarının Gelişimi. Hitit Üniversitesi Sosyal Bilimler Enstitüsü Dergisi, ANARSAN Sempozyumu Özel Saylsl, 11(2), 1347-1362. doi:http://dx.doi.org/10.17218/hititsosbil.463461 
Özkoçak, V, Akın, G, Gültekin, T. (2017). Somatoskopi ve Antropometri Tekniklerinin Adli Bilimler İçin Önemi. Hitit Üniversitesi Sosyal Bilimler Enstitüsü Dergisi, 10(2): 703-714. Doi: 10.17218/hititsosbil.328735

Retief FP. Cilliers L. (2005). The epidemic of Justinian (AD 542): a prelude to the Middle Ages. Acta Theologica 7: 115-127.

Riggs P. Cuff T. (2013). Ladies from Hell, Aberdeen Free Gardeners, and the Russian influenza: An anthropometric analysis of WWI-era Scottish soldiers and civilians. Economics \& Human Biology. 11(1): 69-77.

Singer, M. (2009). Pathogens Gone Wild? Medical Anthropology and the "Swine Flu" Pandemic. Medical Anthropology, 28(3): 199-206.

Stone AC. Ozga AT. (2019). Ancient DNA in the Study of Ancient Disease. Ortner's Identification of Pathological Conditions in Human Skeletal Remains. 3(8): 183-210. DOI: https://doi.org/10.1016/B978-0-12-809738-0.00008-9

Tekeli E. Elma C. (2016). Antropolojik Kemik Örneklerinden Antik DNA Çalışmaları. Antropoloji Dergisi. 32: 23-41.

Varol, N, Gültekin, T. (2016). Etkin Bir Göç Faktörü: Afetler. Antropoloji Dergisi. 32: 43-51. doi: 10.1501/antro_0000000337

W.Qiu S. Rutherford A. Mao C. (2017). The Pandemic and its Impacts. Health, Culture and Society. 9-10: 3-11. DOI 10.5195/hcs.2017.221

Wildoner, D. A. (2016). What's New with Pandemic Flu. Clinical Microbiology Newsletter, 38(4), 27-31.

Zeren F. Hızarcı AE. (2020). COVID-19 Koronavirüsün Hisse Senedi Piyasalarına Etkisi: Seçilmiş Ülkelerden Kanıtlar. Muhasebe ve Finans Incelemeleri Dergisi. 3(1): 78-84.

Zeron HM. Benitez JG. Mdel C. Cardenas A. Delira CN. Bravo GG. (2011). Influenza A (H1N1) was not associated with obesity in pregnant women living in Toluca, México. Rev Salud Publica (Bogota). 13(6):897-907.

\section{İnternet Kaynakları}

T.C. Sağl1k Bakanlığ1, Covid-19 Rehberi, Mart 2020. https://www.tahud.org.tr/file/4f42cbfd-bbd94bf4-91b0-29698f53f198/COVID-19_Rehberi.pdf Erişim Tarihi: 27/03/2020

WHO Director-General's opening remarks at the media briefing on COVID-19 - 11 March 2020. https://www.who.int/dg/speeches/detail/who-director-general-s-opening-remarks-at-themedia-briefing-on-covid-19---11-march-2020 Erişim Tarihi: 2 